Radosław Kuliniak

Uniwersytet Wrocławski, Wrocław

ORCID: 0000-0002-0090-6609

e-mail: kornik90@poczta.onet.pl

Mariusz Pandura

Uniwersytet Wrocławski, Wrocław

ORCID: 0000-0001-5875-2705

e-mail: mariusz.pandura@uni.wroc.pl

\title{
Lwowski życiorys Romana Witolda Ingardena z grudnia 1939 roku
}

W Archiwum Lwowskiego Narodowego Uniwersytetu imienia Iwana Franki zachował się niezmiernie ciekawy dokument dotyczący życia Romana Witolda Ingardena. Jest to własnoręcznie spisane przez fenomenologa Curriculum vitae. Zawiera ono ważne informacje na temat przedwojennej biografii filozofa. Z tych też powodów zdecydowaliśmy się podać je dalej in extenso. Jeszcze bardziej interesująca jest jednak data powstania tego dokumentu. Życiorys został bowiem spisany 22 grudnia 1939 roku we Lwowie. Przypomnijmy, że był to moment, gdy miasto nad Pełtwią znajdowało się od trzech miesięcy pod całkowitą władzą Armii Czerwonej i kontrolujących ją komunistycznych działaczy partyjnych. Okres ten $w$ życiu fenomenologa jest bardzo słabo znany i w dotychczasowych opracowaniach zbywany $\mathrm{w}$ jednym lub kilku zdaniach ${ }^{1}$. Z tego też powodu postanowiliśmy wniknąć w okoliczności powstania tego dokumentu i uwarunkowania ówczesnej pozycji Ingardena.

${ }^{1}$ Zob. Zofia Majewska, Książeczka o Ingardenie. Szkic biograficzny (Lublin: Wydawnictwo Uniwersytetu Marii Curie-Skłodowskiej, 1995), 57. 
12 września 1939 roku rozpoczęło się niemieckie oblężenie Lwowa. W nocy z 18 na 19 września do grona niemieckich napastników dołączyły oddziały Armii Czerwonej. Dwie noce później pozycje niemieckie zostały przekazane oddziałom radzieckim przez wycofujący się w myśl międzypaństwowych ustaleń Wehrmacht. Ostatecznie 22 września doszło do kapitulacji dowodzonych w mieście przez generała Władysława Langnera oddziałów Wojska Polskiego, złożonej na ręce przedstawicieli Armii Czerwonej. Lwów znalazł się pod okupacją radziecką.

Po umocowaniu się władzy radzieckiej w mieście nad Pełtwią - na początku października - doszło do kampanii wyborczej do Zgromadzenia Ludowego Zachodniej Ukrainy. Ten nielegalny organ zebrał się 26-28 października we Lwowie. Otwarcia obrad dokonał profesor Kyryło Studynśkyj. Zgromadzenie wystosowało prośbę do Rady Najwyższej Związku Socjalistycznych Republik Radzieckich o włączenie ziem zachodniej Ukrainy do Ukraińskiej Socjalistycznej Republiki Radzieckiej. Prezydium Rady Najwyższej ZSRR dokonało bezprawnej aneksji południowo-zachodnich terytoriów Rzeczpospolitej Polskiej do Ukraińskiej SRR 1 listopada 1939 roku. Decyzja ta została potwierdzona 15 listopada w Kijowie przez Prezydium Ukraińskiej SRR. Niedługo po tych jednostronnych, niezgodnych z prawem międzynarodowym ustaleniach 29 listopada Prezydium Rady Najwyższej ZSRR zadecydowało o nadaniu obywatelstwa radzieckiego wszystkim byłym obywatelom polskim, którzy znajdowali się na terytorium zachodnich obwodów Ukrainy i Białorusi w chwili, gdy stały się one częścią ZSRR. W efekcie Ingarden miał otrzymać paszport (dowód osobisty) radziecki. Objął go również obowiązek służby wojskowej w Armii Czerwonej ${ }^{2}$. Nie wiemy, kiedy dokładnie filozof wszedł w posiadanie paszportu. Jest bardzo prawdopodobne, że nie stało się to w grudniu 1939 roku, lecz dopiero wówczas, gdy paszport wręczono także jego żonie. Maria Ingardenowa otrzymała swój dokument, w którym figurowała jako Marija-Adielja Josifowna Ingardjen, dopiero 30 marca 1940 roku$^{3}$.

Lwów w ostatnim kwartale 1939 roku był pełen uchodźców, a także osób bezrobotnych. Tych ostatnich było niemal trzydzieści tysięcy, z czego więcej niż jedną trzecią stanowili bieżeńcy, uciekinierzy z terenów zachodniej Polski ${ }^{4}$ Wśród tych osób znajdowała się Jadwiga Ingardenówna, siostra Romana Witolda. Los niezatrudnionych bieżeńców był nie do pozazdroszczenia. W przeważającej mierze żyli oni we Lwowie

${ }_{2}$ Zob. Kronika 2350 dni wojny i okupacji Lwowa. 1 IX 1939-5 II 1946, oprac. G. Mazur, J. Skwara, J. Węgierski (Katowice: Wydawnictwo Unia, 2007), 93.

3 Zob. paszport Marii Ingardenowej, Lwów, 30 marca 1940 roku, w: Archiwum Rodzinne Ingardenów (dalej cytowane jako: ARI).

4 Zob. Grzegorz Hryciuk, Polacy we Lwowie 1939-1944. Życie codzienne (Warszawa: Książka i Wiedza, 2000), 61, 88-89. 
w bardzo trudnych warunkach. Wkrótce miała ich dotknąć fala represji związana z przymusową akcją wysiedleń. Wywózki trwały jednak już od samego początku okupacji, choć po części miały dobrowolny charakter. Około pięćdziesięciu pięciu tysięcy osób podających się za Niemców, w tym dużą grupę Ukraińców, przesiedlono wtedy na tereny Polski okupowane przez III Rzeszę; miało to miejsce od grudnia 1939 roku do stycznia $1940 \mathrm{roku}^{5}$. Nie wiadomo, czy Ingardenom proponowano wyjazd. Nosili niemiecko brzmiące nazwisko, a rodzina Marii Ingardenowej - Polowie (Pohlowie) - była zasymilowanymi Niemcami. Wiele osób, zwłaszcza pozbawionych środków do życia, wyjeżdżało do pracy na wschód Ukrainy, do Zagłębia Donieckiego. W okresie od października do grudnia 1939 roku z Lwowa wyjechało w tamtym kierunku ponad trzynaście tysięcy osób. Większość z nich powróciła przed upływem roku ze względu na złe warunki pracy tam panujące ${ }^{6}$.

5 grudnia 1939 roku pojawił się rozkaz Komisariatu Wojennego miasta Lwowa, który nakazywał rejestrację od 7 grudnia wszystkich mężczyzn urodzonych między 1890 a 1921 rokiem7 ${ }^{7}$. Ingarden, jako urodzony w 1893 roku, był objęty tym rozkazem i musiał się zarejestrować. Jak wiemy, choremu od młodości na serce fenomenologowi udało się już wcześniej uniknąć hekatomby I wojny światowej. Odmówiono mu też udziału w walkach obronnych w 1920 roku. Tym razem nie mógł jednak liczyć na podobne traktowanie. Musiał wziąć pod uwagę, że w każdej chwili może w budionówce ozdobionej naszytą na niej czerwoną gwiazdą oraz z karabinem (lub nawet bez niego) w dłoniach wylądować w okopach, chociażby w Karelii, i być zmuszonym do walki z Finami.

W nocy z 9 na 10 grudnia 1939 roku doszło do akcji aresztowań przeprowadzonej przez NKWD na terytoriach Rzeczypospolitej Polskiej. We Lwowie aresztowano ponad dwieście osób ${ }^{8}$. Nastąpił wówczas ogromny wstrząs w życiu fenomenologa. Aresztowano jego syna, Jerzego Ingardena9. Wraz z nim w więzieniu osadzono także Adama Krzyża, Jerzego Borowego, Gustawa Pistla, Jerzego Kucharskiego, Leonarda Chmielewskiego i Zbigniewa Chożewskiego. Wszyscy oni zostali oskarżeni o uczestniczenie $\mathrm{w}$ pracach tajnego kontrrewolucyjnego związku „Polska Organizacja Partyzancka"10. Mieli ustalać dokładne położenie jednostek wojskowych Armii Czerwonej. Twierdzono, że w centrum ich

5 Zob. Kronika 2350 dni wojny, 97.

6 Zob. Hryciuk, Polacy we Lwowie, 62-63.

7 Zob. Kronika 2350 dni wojny, 95.

8 Zob. Hryciuk, Polacy we Lwowie, 36.

9 Losy swojego brata Jerzego opisał dokładnie we wspomnieniach Roman Stanisław Ingarden. Zob. Roman Stanisław Ingarden, Roman Witold Ingarden. Życie filozofa w okresie toruńskim (1921-1926) (Toruń: Wydawnictwo Naukowe UMK, 2000), „B. Wojenne i powojenne losy mojego brata Jurka, 1939-1949”, 156-172.

10 Zob. tamże. 
zainteresowania znajdowały się magazyny z amunicją które zamierzali wysadzić. Rzekomo prowadzili także działalność wywiadowcza, starając się ustalić możliwości wejścia do budynku lokalnego dowództwa Armii Czerwonej, jak również miejscowego NKWD. Funkcję wywiadowców miało pełnić grono zwerbowanych przez przywódców organizacji trzydziestu dziewcząt od trzynastego do szesnastego roku życia. Z materiałów śledztwa wynika, że Jerzy Ingarden był dowódcą jednej z „grup bojowych" wspomnianej organizacji1".

W konsekwencji 12 grudnia 1939 roku w mieszkaniu Ingardenów przy ul. Pawlikowskiego 19 nastąpiło przeszukanie przeprowadzone przez 2 Wydział UGB NKWD obwodu lwowskiego. Dokonano go po wprowadzeniu do mieszkania aresztowanego syna, Jerzego. Stało się to w obecności filozofa. W Archiwum Rodzinnym Ingardenów zachował się protokół przeszukania podpisany zarówno przez Romana Witolda Ingardena, jak i przez Jerzego Ingardena ${ }^{12}$. Jerzy Ingarden był w późniejszym czasie przetrzymywany w jednym z więzień lwowskich (w słynnych Brygitkach), następnie przetransportowano go do więzienia przesyłkowego w Charkowie, gdzie jego pobyt został poświadczony w kwietniu 1940 roku. Później wywieziono go na wschodnie tereny ZSRR do obozu pracy. Udało mu się stamtąd wydostać z Polskimi Siłami Zbrojnymi w ZSRR. Został żołnierzem 6 Batalionu „Dzieci Lwowskich” 6 Lwowskiej Dywizji Piechoty pod dowództwem generała brygady Michała Karaszewicza-Tokarzewskiego ${ }^{13}$. Przebywał w Iranie i Indiach, wreszcie pełnił służbę wojskową jako lotnik uczestniczący w zrzutach organizowanych z Wielkiej Brytanii nad okupowaną Warszawą ${ }^{14}$. Po wojnie za sprawą swego ojca powrócił do kraju. Był już ciężko chory. Zmarł w 1949 roku $^{15}$.

Zaledwie dzień przed napisaniem Curriculum vitae we Lwowie, tj. 21 grudnia 1939 roku, decyzją Ludowego Komisarza Finansów Ukraińskiej

11 Zob. tamże, a także „List Iwana A. Sierowa, Ludowego Komisarza Spraw Wewnętrznych Ukraińskiej Socjalistycznej Republiki Radzieckiej do Ławrentina P. Berii, Ludowego Komisarza Spraw Wewnętrznych Związku Socjalistycznych Republik Radzieckich, [brak lokalizacji miejsca], marzec 1940 r. [brak daty dziennej]", w: Polska i Ukraina w latach trzydziestych-czterdziestych XX wieku. Nieznane dokumenty z archiwów stużb specjalnych. Polskie podziemie 1939-1941, t. 1, red. Zuzanna Gajowniczek i in. (Lwów-Kołomyja-Stryj-Złoczów-Warszawa-Kijów, 1998), 45-51. Zob. też Roman Stanisław Ingarden, Roman Witold Ingarden, „B. Wojenne i powojenne losy mojego brata Jurka, 1939-1949", 156-172. Zob. relacja Jerzego Kucharskiego: archiwa.pilsudski.org/dokument.php?nonav=0\&nrar=701\&nrzesp=152\&nrzesp2=2\&sygn=12\&seria =2\&handle=701.180/19680 (film oraz transkrypt), dostęp: 12 grudnia 2019 roku.

12 Zob. Протокол домашнего обыска, [Lwów], 12 grudnia 1939 roku, w: ARI.

13 Zob. relacja Jerzego Kucharskiego.

${ }_{14}$ Zob. odpis listu Jerzego Ingardena do Haliny Grochowskiej z Londynu z 9 lipca 1946 roku, maj 1977 roku [brak daty dziennej i miejsca dokonania odpisu], w: ARI.

15 Zob. Ingarden, Roman Witold Ingarden, 156-172. 
Socjalistycznej Republiki Radzieckiej doszło do unieważnienia polskiego złotego i jako jedyną obowiązującą walutę wprowadzono rubla. W efekcie wszystkie dotychczasowe oszczędności ludności miasta nad Pełtwią gromadzone $\mathrm{w}$ złotówkach stały się $\mathrm{z}$ dnia na dzień bezwartościowe ${ }^{16}$. Ogłoszone poprzedniego dnia zarządzenie nie dawało niemal żadnej możliwości wymiany waluty, zwłaszcza że z książeczek oszczędnościowych zezwolono wypłacić jedynie równowartość trzystu rubli (po kursie jeden rubel za jednego złotego) ${ }^{17}$. Ta sytuacja stawiała stabilność ekonomiczną Ingardenów pod znakiem zapytania i uzależniała rodzinę fenomenologa od pensji otrzymywanej na uczelni. W późniejszym zaś czasie swoboda Ingardenów była ograniczana przez „dobrowolny” wykup obligacji państwowych ${ }^{18}$.

W tym czasie lwowską Alma Mater czekały zmiany zainicjowane przez komunistów. W zapomnienie poszły dawne zapowiedzi Ołeksandra Kornijczuka wygłoszone na wiecu studentów i pracowników Uniwersytetu Lwowskiego, który odbył się 29 września 1939 roku. Zapewniano wówczas, że uczelnia zachowa swój polski charakter. Trwało to jedynie półtora miesiąca. Wkrótce rozpoczęto wprowadzać intensywną sowietyzację i ukrainizację. Dawny Uniwersytet Jana Kazimierza we Lwowie na skutek decyzji jego Rady Naukowej z grudnia 1939 roku miano przemianować na Ukraiński Lwowski Państwowy Uniwersytet. Dopiero w wyniku wydarzeń na wiecu 3 stycznia 1940 roku zdecydowano się w nowym statucie uczelni zawrzeć nazwę Lwowski Uniwersytet Państwowy im. Iwana Franki ${ }^{19}$. Statut ten został zatwierdzony 2 lutego przez Wszechzwiązkowy Komitet do spraw Szkół Wyższych przy Radzie Komisarzy Ludowych ZSRR ${ }^{20}$.

W tych okolicznościach 23 grudnia Ingarden wypełnił druk osobowej kadry ewidencyjnej. Jednym z jego załączników było sporządzone dzień wcześniej Curriculum vitae ${ }^{21}$. Znalazły się tam również: spis prac

16 Zob. Kronika 2350 dni wojny, 101.

17 Zob. tamże, 96-97, 100.

18 Te radzieckie obligacje z roku 1940 do dziś zachowały się w ARI.

19 Zob. Hryciuk, Polacy we Lwowie, 39-43.

20 Zob. Jan Draus, Uniwersytet Jana Kazimierza. Portret kresowej uczelni (Kraków: Księgarnia Akademicka, 2007), 80-81.

${ }^{21}$ Zob. Curriculum vitae Romana Witolda Ingardena, Lwów, 22 grudnia 1939 roku, Archiwum Lwowskiego Narodowego Uniwersytetu imienia Iwana Franki (Архів ПьвівськогоНаціональногоУніверситетуімені ІванаФранка), оп. 1,ед.хр.73:Личное дело профессора немеиякой литературы Ингардена Романа Романовича, k. 27r-27v. 
fenomenologa ${ }^{22}$, odbitka dyplomu doktorskiego ${ }^{23}$, odpis nominacji na profesora ${ }^{24}$ oraz odpis zatwierdzenia habilitacji ${ }^{25}$. Dokumenty te zachowały się w Archiwum Lwowskiego Narodowego Uniwersytetu imienia Iwana Franki. W karcie ewidencyjnej fenomenolog oświadczył, że zna słabo francuski, angielski, łacinę i grekę. Dysponuje natomiast dobrą znajomością języka niemieckiego ${ }^{26}$. Niewątpliwie deklaracja ta była jednym z powodów, dla których profesora niemile widzianej burżuazyjnej filozofii zatrudniono później przy Katedrze Języka i Literatury Niemieckiej. Dane te zostały potwierdzone przez dostępną w aktach uniwersyteckich deklarację Ingardena z 23 lutego 1935 roku $^{27}$. Zachowała się ona jednak nie w przedwojennej dokumentacji, znajdującej się w Państwowym Archiwum Obwodu Lwowskiego, lecz w dokumentach z lat 1939-1941, przechowywanych w Archiwum Lwowskiego Narodowego

${ }_{22}$ Zob. spis prac prof. dr. R. Ingardena (Chronologicznie ułożony), [Lwów, 1939 roku], Archiwum Lwowskiego Narodowego Uniwersytetu imienia Iwana Franki (Архів Львівського Національного Університету імені Івана Франка), оп. 1, ед. хр. 73: Аичное дело профессора немецкой литературы Ингардена Романа Романовича, k. 23r-26r.

${ }^{23}$ Zob. odbitka dyplomu doktorskiego Romana Witolda Ingardena (z naniesionym zaświadczeniem o zgodności z oryginałem wystawionym przez Władysława Podlachę, Dziekana Wydziału Humanistycznego U.J.K. 6 marca 1931 roku), Fryburg, 23 lutego 1918 roku, Archiwum Lwowskiego Narodowego Uniwersytetu imienia Iwana Franki (Архів Львівського Національного Університету імені Івана Франка), оп. 1, ед. хр. 73: Аичное дело профессора немецзкой литературы Ингардена Романа Романовича, k. 10r.

${ }_{24}$ Zob. odpis nominacji Romana Witolda Ingardena na profesora nadzwyczajnego, Warszawa, 23 listopada 1933 roku, [poświadczony pomiędzy wrześniem i grudniem 1939 roku], Archiwum Lwowskiego Narodowego Uniwersytetu imienia Iwana Franki (Архів Аьвівського Національного Університету імені Івана Франка), оп. 1, ед. хр. 73: Аичное дело профессора немецкой литературы Ингардена Романа Романовича, k. 28r.

25 Zob. odpis zatwierdzenia habilitacji Romana Witolda Ingardena, Warszawa, 4 marca 1925 roku, [poświadczony pomiędzy wrześniem i grudniem 1939 roku], Archiwum Lwowskiego Narodowego Uniwersytetu imienia Iwana Franki (Архів Львівського Національного Університету імені Івана Франка), оп. 1, ед. хр. 73: Аичное дело профессора немецзкой литературы Ингардена Романа Романовича, k. 29r.

26 Zob. Особистний листок по обліку кадрів - Ingarden Roman Witold, Lwów, 23 grudnia 1939 roku, Archiwum Lwowskiego Narodowego Uniwersytetu imienia Iwana Franki (Архів Львівського Національного Університету імені Івана Франка), оп. 1, ед. хр. 73: Аичное дело профессора немец̧кой хитературы Ингардена Романа Романовича, k. 20r-21r.

${ }_{27}$ Zob. deklaracja Romana Witolda Ingardena dotycząca znajomości języków, Lwów, 23 lutego 1935 roku, Archiwum Lwowskiego Narodowego Uniwersytetu imienia Iwana Franki (Архів Аьвівського Національного Університету імені Івана Франка), оп. 1, ед. хр. 73: Аичное дело профессора немецъкой литературы Ингардена Романа Романовича, k. 16. 
Uniwersytetu. Świadczy to o tym, że była wykorzystywana podczas postępowania kwalifikacyjnego fenomenologa w tamtych latach.

Ingarden przeszedł przez sito komunistycznej weryfikacji i pomimo tego, że uznawano go za "element niepewny", pozostał pracownikiem Uniwersytetu Lwowskiego. Poświadcza to między innymi zachowana w Archiwum Rodzinnym Ingardenów jego legitymacja pracownika Lwowskiego Państwowego Uniwersytetu im. Iwana Franki ${ }^{28}$. Ponadto zlikwidowano Ingardenowi jego Katedrę Filozofii. Wiodącą rolę na uczelni miały pełnić międzywydziałowa Katedra Marksizmu-Leninizmu oraz Katedra Materializmu Dialektycznego i Historycznego ${ }^{29}$. Ingarden został skierowany na inne tory dydaktyczne. Od 11 stycznia pracował jako profesor przy Katedrze Języka i Literatury Niemieckiej na Wydziale Filologicznym ${ }^{30}$. Katedrą tą kierował Kazimierz Kolbuszew$\mathrm{ski}^{31}$. Ingarden wykładał tam teorię literatury ${ }^{32}$. Wystawiona na początku 1940 roku opinia weryfikacyjna Kyryły Studynśkyja, prorektora do spraw naukowych Lwowskiego Państwowego Uniwersytetu, i Jurija Polanśkyja, sekretarza naukowego Rady Lwowskiego Państwowego Uniwersytetu, zaświadcza, że fenomenolog zasługuje na pełnienie funkcji profesora i na stopień naukowy doktora ${ }^{33}$.

Można przypuszczać, że Ingarden z czasem przystąpił do Związku Zawodowego Pracowników Uniwersytetu, czyli profspiłki. Członkostwo wykładowców uniwersyteckich było obowiązkowe, dlatego stopniowo zgłaszali oni do niej akces. Przewodniczącym profspitki na Uniwersytecie Lwowskim był od października 1939 roku dawny rektor, Stanisław

${ }^{28}$ Zob. legitymacja pracownicza Romana Witolda Ingardena z Lwowskiego Państwowego Uniwersytetu im. Iwana Franki, [Lwów], 1940 rok (brak daty dziennej), w: ARI.

${ }^{29}$ Zob. Adam Redzik, „Uniwersytet w latach 1939-1946”, w: Academia militans. Uniwersytet Jana Kazimierza we Lwowie, red. Adam Redzik (Kraków: Wydawnictwo Wysoki Zamek, 2015), 966-967.

${ }_{30}$ Zob. ankieta personalna Romana Witolda Ingardena, Kraków, 14 czerwca 1950 roku, Archiwum Uniwersytetu Jagiellońskiego, S III 246, Roman Ingarden; Czesław Madajczyk, Ryszard Torzecki, „Świat kultury i nauki Lwowa (1936-1941)”, Dzieje Najnowsze, R. 14, 1982, nr 1-4, 47-63, 57-58; Majewska, Ksiażeczka o Ingardenie, 57.

31 Zob. Jan Draus, Uniwersytet Jana Kazimierza, 81; Adam Redzik, Uniwersytet w latach 1939-1946, 955.

${ }_{32}$ Zob. Curriculum vitae Romana Witolda Ingardena, Kraków, 14 maja 1948 roku, Archiwum Uniwersytetu Jagiellońskiego, S III 246, Roman Ingarden.

${ }_{33}$ Zob. oświadczenie Kyryły Studynśkyja, prorektora do spraw naukowych Lwowskiego Państwowego Uniwersytetu i Jurija Polanśkyja, sekretarza naukowego Rady Lwowskiego Państwowego Uniwersytetu, Lwów, 1940 roku [brak daty dziennej], Archiwum Lwowskiego Narodowego Uniwersytetu imienia Iwana Franki (Архів Аьвівського Національного Університету імені Івана Франка), оп. 1, ед. хр. 73: Аичное дело профессора немецккой литературы Ингардена Романа Романовича, k. 22r. 
Kulczyński, późniejszy rektor połączonych uniwersytetu i politechniki we Wrocławiu ${ }^{34}$. Do profspitki dopuszczono nawet Romana Longchampsa de Bériera, który wsławił się wprowadzeniem tzw. getta ławkowego na Uniwersytecie Jana Kazimierza ${ }^{35}$.

Warunki pracy dydaktycznej zmieniły się jednak zupełnie w porównaniu do sytuacji sprzed wybuchu wojny. Wśród studentów nastąpił gwałtowny odpływ Polaków. Przeważali wówczas Żydzi i Ukraińcy ${ }^{36}$. Wśród uczestników zajęć nie brakowało donosicieli z Komsomołu, którzy skrzętnie notowali każde wygłoszone przez prowadzących niepoprawne słowo ${ }^{37}$. Ingarden mógł wykładać po polsku, gdyż wydany przez lwowskie władze w styczniu 1940 roku nakaz prowadzenia na uniwersytecie zajęć w języku ukraińskim został cofnięty za sprawą interwencji Stalina, którego poprosiła o to Wanda Wasilewska ${ }^{38}$. Zajęcia na Uniwersytecie Lwowskim fenomenolog prowadził aż do wkroczenia wojsk niemieckich do Lwowa 30 czerwca 1941 roku.

Choć obciążony dydaktyką Ingarden nie publikował, nie zaniedbywał jednocześnie pracy naukowej. $W$ trakcie pierwszej okupacji radzieckiej był zdania, że „nie należy pisać prac naukowych dla Sowietów, jeśli się nie musi". Dlatego też jego teksty, które wówczas powstawały, lądowały w szufladzie i czekały na właściwy czas, by je opublikować39. Ówczesna twórczość Ingardena dotyczyła zresztą głównie teorii literatury. Jego najważniejsze, niedokończone dzieło z tego czasu to Poetyka. O swojej pracy w czasie pierwszej okupacji radzieckiej Ingarden napisał znamiennie do Stefana Szumana we wrześniu 1941 roku: „W zakresie filozofii przez ten czas w ogóle nie pracowałem, gdyż to było wykluczone" 40 .

\section{Bibliografia}

Ankieta personalna Romana Witolda Ingardena, Kraków, 14 czerwca 1950 roku, Archiwum Uniwersytetu Jagiellońskiego, S III 246, Roman Ingarden.

34 Zob. Jan Draus, Uniwersytet Jana Kazimierza we Lwowie 1918-1946. Portret kresowej uczelni (Kraków: Księgarnia Akademicka, 2007), 87.

35 Zob. Tadeusz Tomaszewski, Lwów 1940-1944. Pejzaż psychologiczny (Warszawa: Uni-Druk, 1996), 49-50.

36 Zob. Draus, Uniwersytet Jana Kazimierza, 83, 86.

37 Zob. tamże, 87.

38 Zob. tamże, 84-85.

39 Zob. Tomaszewski, Lwów 1940-1944, 37.

${ }^{40}$ List Romana Witolda Ingardena do Stefana Szumana, 14 września 1941 roku, cyt. za: Marek Mariusz Tytko, „Mjr prof. Stefan Szuman w walce o niepodległość Polski (1939-1945)", Sowiniec, 44 (2014): 66. 
Curriculum vitae Romana Witolda Ingardena, Kraków, 14 maja 1948 roku, Archiwum Uniwersytetu Jagiellońskiego, S III 246, Roman Ingarden.

Curriculum vitae Romana Witolda Ingardena, Lwów, 22 grudnia 1939 roku, Archiwum Lwowskiego Narodowego Uniwersytetu imienia Iwana Franki (Архів Аьвівського Національного Університету імені Івана Франка), оп. 1, ед. хр. 73: Аичное дело профессора немецкой литературь Ингардена Романа Романовича, k. 27r-27v.

Deklaracja Romana Witolda Ingardena dotycząca znajomości języków, Lwów, 23 lutego 1935 roku, Archiwum Lwowskiego Narodowego Uniwersytetu imienia Iwana Franki (Архів Львівського Національного Університету імені Івана Франка), оп. 1, ед. хр. 73: Аичное дело профессора немеикой литературы Ингардена Романа Романовича, k. 16.

Draus Jan. 2007. Uniwersytet Jana Kazimierza we Lwowie 1918-1946. Portret kresowej uczelni. Kraków: Księgarnia Akademicka.

Hryciuk Grzegorz. 2000. Polacy we Lwowie 1939-1944. Życie codzienne. Warszawa: Książka i Wiedza.

Ingarden Roman Stanisław. 2000. „Wojenne i powojenne losy mojego brata Jurka". W: Roman Witold Ingarden. Życie filozofa w okresie toruńskim (1921-1926). 156-172. Toruń: Wydawnictwo UMK.

Kronika 2350 dni wojny i okupacji Lwowa. 1 IX 1939-5 II 1946, oprac. Grzegorz Mazur, Jerzy Skwara, Jerzy Węgierski. Katowice: Wydawnictwo Unia, 2007.

Legitymacja pracownicza Romana Witolda Ingardena z Lwowskiego Państwowego Uniwersytetu im. Iwana Franki, [Lwów], 1940 rok (brak daty dziennej). W: ARI.

List Iwana A. Sierowa, Ludowego Komisarza Spraw Wewnętrznych Ukraińskiej Socjalistycznej Republiki Radzieckiej do Ławrentina P. Berii, Ludowego Komisarza Spraw Wewnętrznych Związku Socjalistycznych Republik Radzieckich, [brak lokalizacji miejsca], marzec 1940 r. [brak daty dziennej]. W: Polska i Ukraina w latach trzydziestych-czterdziestych XX wieku. Nieznane dokumenty z archiwów stużb specjalnych. Polskie podziemie 1939-1941, red. Zuzanna Gajowniczek i in., t. 1: Lwów-Kołomyja-Stryj-Złoczów, Warszawa-Kijów 1998, 45-51.

Madajczyk Czesław, Torzecki Ryszard, „Świat kultury i nauki Lwowa (1936-1941)", Dzieje Najnowsze, R. 14, 1-4 (1982): 47-63, 57-58.

Majewska Zofia. 1995. Ksiażeczka o Ingardenie. Szkic biograficzny. Lublin: Wydawnictwo Uniwersytetu Marii Curie-Skłodowskiej.

Odbitka dyplomu doktorskiego Romana Witolda Ingardena (z naniesionym zaświadczeniem o zgodności z oryginałem wystawionym przez Władysława Podlachę, Dziekana Wydziału Humanistycznego U.J.K. 6 marca 1931 roku), Fryburg, 23 lutego 1918 roku, Archiwum Lwowskiego Narodowego Uniwersytetu imienia Iwana Franki (Архів Аьвівського Національного Університету імені Івана Франка), оп. 1, ед. хр. 73: Аичное дело профессора немецикой литературы Ингардена Романа Романовича, k. 10r. 
Odpis listu Jerzego Ingardena do Haliny Grochowskiej z Londynu z 9 lipca 1946 roku, maj 1977 roku [brak daty dziennej i miejsca dokonania odpisu]. W: ARI.

Odpis nominacji Romana Witolda Ingardena na profesora nadzwyczajnego, Warszawa, 23 listopada 1933 roku, [poświadczony pomiędzy wrześniem i grudniem 1939 roku], Archiwum Lwowskiego Narodowego Uniwersytetu imienia Iwana Franki (Архів Дьвівського Національного Університету імені Івана Франка), оп. 1, ед. хр. 73: Аичное дело профессора немеиякой литературы Ингардена Романа Романовича, k. 28r.

Odpis zatwierdzenia habilitacji Romana Witolda Ingardena, Warszawa, 4 marca 1925 roku, [poświadczony pomiędzy wrześniem i grudniem 1939 roku], Archiwum Lwowskiego Narodowego Uniwersytetu imienia Iwana Franki (Архів Аьвівського Національного Університету імені Івана Франка), оп. 1, ед. хр. 73: Аичное дело профессора немецзкой литературы Ингардена Романа Романовича, k. 29r.

Особистний дисток по обліку кадрів - Ingarden Roman Witold, Lwów, 23 grudnia 1939 roku, Archiwum Lwowskiego Narodowego Uniwersytetu imienia Iwana Franki (Архів Аьвівського Національного Університету імені Івана Франка), оп. 1, ед. хр. 73: Аичное дело профессора немецкой литературы Ингардена Романа Романовича, k. 20r-21r.

Oświadczenie Kyryły Studynśkyja, prorektora do spraw naukowych Lwowskiego Państwowego Uniwersytetu i Jurija Polanśkyja, sekretarza naukowego Rady Lwowskiego Państwowego Uniwersytetu, Lwów, 1940 roku [brak daty dziennej], Archiwum Lwowskiego Narodowego Uniwersytetu imienia Iwana Franki (Архів Иьвівського Національного Університету імені Івана Франка), оп. 1, ед. хр. 73: Аичное дело профессора немеикой литературы Ингардена Романа Романовича, k. 22r.

Paszport Marii Ingardenowej, Lwów, 30 marca 1940 roku. W: Archiwum Rodzinne Ingardenów (dalej cytowane jako: ARI).

Протокол домашнего обыска, [Lwów], 12 grudnia 1939 roku. W: ARI.

Redzik Adam. 2015. „Uniwersytet w latach 1939-1946”. W: Adam Redzik, Academia militans. Uniwersytet Jana Kazimierza we Lwowie. Kraków: Wydawnictwo Wysoki Zamek.

Relacja Jerzego Kucharskiego: archiwa.pilsudski.org/dokument.php?nonav $=0$ \&nrar $=701 \&$ nrzesp $=152 \&$ nrzesp $2=2 \&$ sygn $=12$ \&seria $=2 \&$ hand le=701.180/19680 (film oraz transkrypt), dostęp: 12 grudnia 2019 roku.

Spis prac prof. dr. R. Ingardena (Chronologicznie ułożony), [Lwów, 1939 r.], Archiwum Lwowskiego Narodowego Uniwersytetu imienia Iwana Franki (Архів Иьвівського Національного Університету імені Івана Франка), оп. 1, ед. хр. 73: Аичное дело профессора немецькой литературь Ингардена Романа Романовича, k. 23r-26r.

Tomaszewski Tadeusz. 1996. Lwów 1940-1944. Pejzaż psychologiczny, Warszawa: Uni-Druk. 


\section{Streszczenie}

Artykuł ten jest wprowadzeniem do prezentacji własnoręcznie napisanego w grudniu 1939 roku przez Ingardena Curriculum vitae. Podobnych życiorysów filozofa w jego Archiwum Rodzinnym jest wiele. Ingarden pisał je przeważnie ze względu na własne postępowania awansowe, jednocześnie pozostawiając kopię w swoich papierach. Niniejszy życiorys został sporządzony w trudnych okolicznościach. Stało się to na początku pierwszej okupacji Lwowa przez Armię Czerwona, gdy nowe władze weryfikowały personel lwowskiego uniwersytetu.

Słowa kluczowe: Roman Witold Ingarden, Curiculum vitae, Lwów, okres okupacji sowieckiej.

\section{Summary}

This article is an introduction to the presentation of Roman Ingarden's Curriculum Vitae written by him in December 1939. There are many similar biographies which describe the philosopher's life in his Family Archive. Ingarden wrote them mostly because he wished to promote himself, leaving at the same time a copy of each in his papers. This curriculum vitae was prepared in difficult circumstances, at the beginning of the first occupation of Lviv by the Red Army, when new authorities verified the Lviv University staff.

Keywords: Roman Witold Ingarden, Curiculum vitae, Lviv, the period of Soviet occupation. 